\title{
BILATERAL VERTEBRAL ARTERY DISSECTION - MULTIPLE ARTERY AFFECTION OR EARLY RECURRENCE?
}

\author{
Arijana Lovrenčić-Huzjan ${ }^{1,2}$, Marijana Bosnar-Puretić ${ }^{1}$, \\ Vlasta Vuković-Cvetković ${ }^{3}$ and Vanja Bašić Kes ${ }^{1,2}$ \\ ${ }^{1}$ Clinical Department of Neurology, Sestre milosrdnice University Hospital Center, Zagreb, Croatia; \\ ${ }^{2}$ School of Dental Medicine, University of Zagreb, Zagreb, Croatia; \\ ${ }^{3}$ Danish Headache Center, Department of Neurology, Rigshospitalet - Glostrup, \\ University of Copenhagen, Copenhagen, Denmark
}

\begin{abstract}
SUMMARY - In a certain percentage of patients with craniocervical artery dissection, dissections affect multiple arteries. Some investigators consider that the dissections diagnosed as multiple might have occurred sequentially within a short time frame. We describe an oligosymptomatic patient with bilateral progressive vertebral artery dissection. Careful history taking added new data on transient left arm weakens two months earlier, as a possibility of the earlier disease onset.
\end{abstract}

Key words: Vertebral artery dissection, bilateral; Stroke; Neurosonology; Monitoring

\section{Introduction}

Craniocervical artery dissection (CCAD) corresponds to a hematoma in the wall of the internal carotid or vertebral artery, and is a major cause of stroke in young and middle aged adults ${ }^{1}$. Oligosymptomatic forms usually are undiagnosed ${ }^{2}$. Pathophysiology of CCAD is still poorly understood ${ }^{3}$. The disease is in most instances multifactorial. These patients seem to have a predisposing arterial wall weakness, which could be in part genetically determined, or uncommon vascular disorders such as fibromuscular dysplasia that makes these patients prone to bleeding within a vessel wall after a minor trauma. Additionally, recent infection, migraine, low body mass index (BMI), hyperhomocysteinemia, and 677TT genotype of the 5,10-methylenetetrahydrofolate reductase gene (MTHFR 677TT) have been suggested as predispos-

Correspondence to: Arijana Lovrenčić-Huzjan, $M D, P h D$, Clinical Department of Neurology, Sestre milosrdnice University Hospital Center, Vinogradska c. 29, HR-10000 Zagreb, Croatia

E-mail: arijana.huzjan@gmail.com

Received January 11, 2016, accepted June 28, 2016 ing factors, although the evidence is sparse ${ }^{1,4-7}$. Dissected artery heals within a short period of time, the hematoma usually resolves within 6 months, and the outcome is mostly good.

In approximately $15 \%$ of the cases, CCAD affects multiple arteries ${ }^{8-11}$. Some CCAD cases diagnosed as multiple might have occurred sequentially within a short time frame, and some investigators consider early CCAD recurrences and multiple dissections as the same entity ${ }^{3}$.

While magnetic resonance imaging (MRI) and magnetic resonance angiography (MRA) confirm the diagnosis, neurosonology enables noninvasive bedside screening and evaluation of CCAD, and also is an ideal tool for monitoring of the course of the disease ${ }^{12-20}$.

We describe an oligosymptomatic patient with bilateral progressive vertebral artery dissection.

\section{Case Report}

A 40-year-old female presented to the neurological emergency room (NER) due to general weakness, pain in the neck, dizziness and vomiting. She complained 


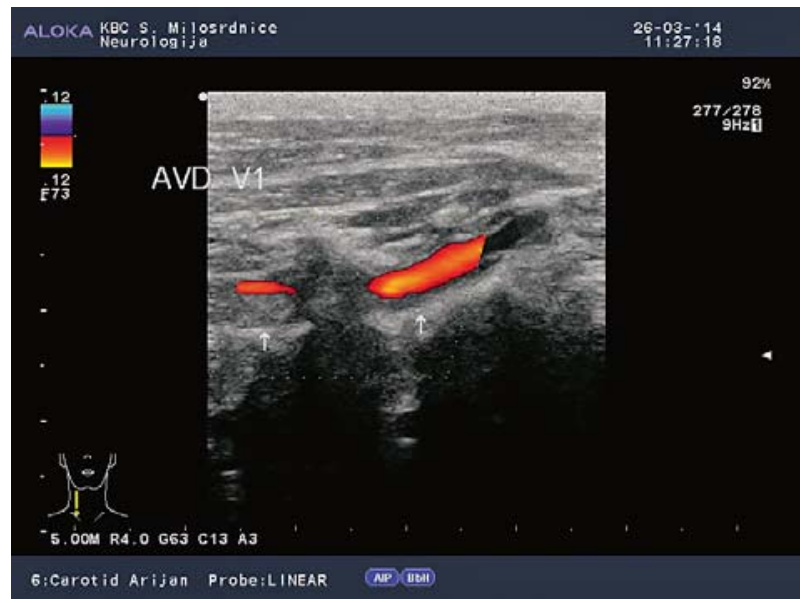

Fig. 1. Hematoma in the right vertebral artery starting in the distal part of V1 segment.

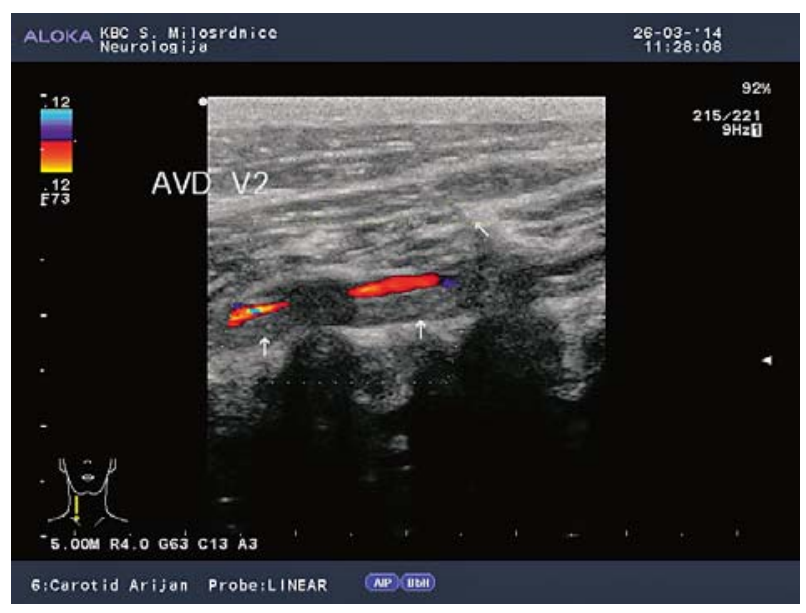

Fig. 2. Extension of the right vertebral artery hematoma in V2 segment.

of headache that had started 10 days earlier, of sudden onset, and was intensive for several days. Four days before presentation to the NER, she experienced transient visual disturbances simultaneously with headache. She described visual disturbances as blurred vision at the edges of the vision field spreading to the center of the visual field. The visual disturbances spontaneously disappeared, but headache persisted. She complained of having been under stress for a longer time, especially in the past few weeks. She denied recent head or neck trauma.

Her past history revealed her having suffered from migraine with aura for several years. The aura symptoms presented as blurred vision and paresthesia occurring before headache onset. For several years, she

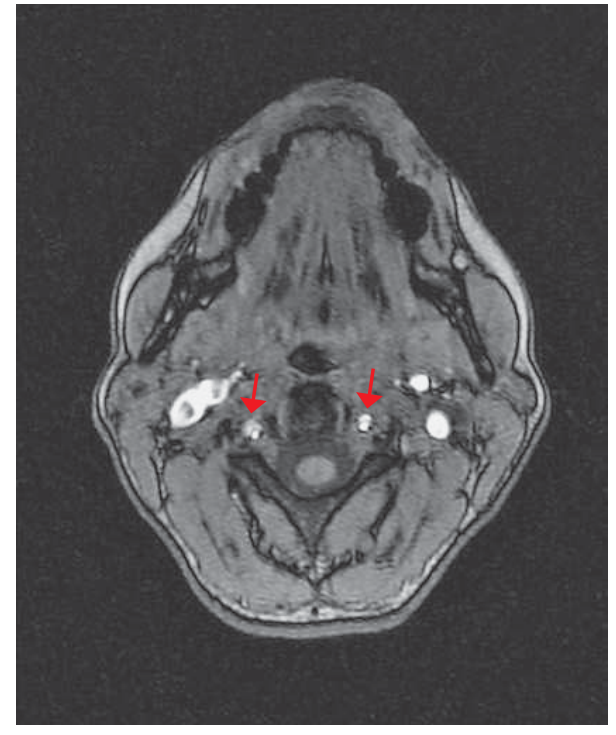

Fig. 3. Brain magnetic resonance imaging scan showing bilateral vertebral artery hematoma (by courtesy of Dijana Zadravec, Clinical Department of Radiology, Sestre milosrdnice University Hospital Center, Zagreb).

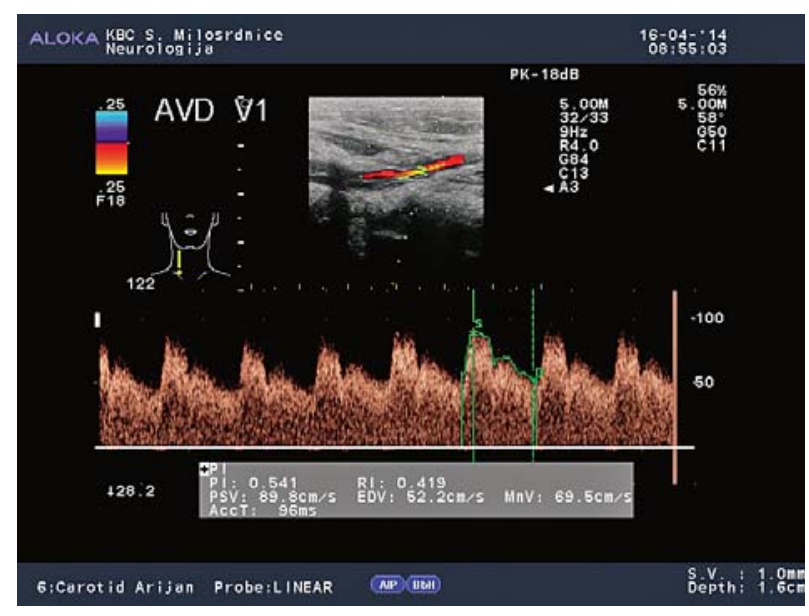

Fig. 4. Enlargement of the hematoma in distal V1 and proximal V2 segment of the right vertebral artery.

has also been suffering from hemifacial spasm on the left side and was treated with botulin toxin with good clinical effect; the last application was 5 months before. Three years before, she had been treated for hyperthyroidism, had undergone thyroidectomy, and currently was on substitutional therapy. The last follow-up examination 2 months before showed normal levels of thyroid hormones. Preventive screening examination including noninvasive ultrasound of carotid arteries at another institution was performed a month 
before and was normal. She was normotensive, lefthanded, and nonsmoker. She denied alcohol consumption.

On admission to the NER, the patient's neurological finding was normal except for hemifacial spasm on the left side and bilateral exophthalmos. Body mass index was 18. Blood pressure at admission was 150/100 $\mathrm{mm} \mathrm{Hg}$, pulse rate was $74 \mathrm{~b} / \mathrm{min}$. Brain computed tomography $(\mathrm{CT})$ scan was normal. Laboratory testing showed leukocytosis, and other findings were normal. After analgesic and sedative therapy, the patient was discharged. The next day she presented again to the NER due to persistent dizziness and mild stiffness of the neck, with negative meningeal sign. Brain CT scan was repeated and was normal again.

Although neurological findings were normal, due to the presenting symptoms the patient was admitted to the Department of Neurology for suspicion of the possible cerebellar infarct. Sedative and antiemetic therapy was introduced and diagnostic work-up performed. Neurosonology testing of carotid arteries was normal, but revealed hematoma in the right vertebral artery starting in the distal part of the V1 segment (Fig. 1), extending throughout the V2 (Fig. 2) and V3 segment, and a smaller one in the left vertebral artery in the V2 segment. Careful history taking added new data on transient left arm weakness two months before. Anticoagulation with low-molecular-weight heparin (LMWH) was initiated. The next day, the diagnosis of vertebral artery dissection was confirmed with MRI and MRA (Fig. 3). Brain MRI showed multiple vascular lesions in both cerebellum and left thalamus. Brain MRI confirmed bilateral vertebral artery hematoma, and MRA showed dissection of the right vertebral artery involving the whole V1, V2 and V3 segments, occluding the V4 segment, and dissection of the left artery involving the V3 segment with insufficient filling of the V4 segment and basilar artery. Daily neurosonologic monitoring showed enlargement of the hematoma in size and length in both vertebral arteries (Fig. 4). Work-up did not reveal monogenetic connective tissue disease, vasculitis, or other underlying disease.

Anticoagulation with LMWH was introduced after establishment of the diagnosis based on neurosonologic diagnostics performed on the first day. Throughout the patient's hospital stay, blood pressure was normal without medication. Her symptoms regressed and after 2 weeks, neurosonologic findings showed no further progression of dissection. Therapy with warfarin was introduced and the patient was discharged when the INR reached therapeutic range.

\section{Discussion}

We describe a patient with progressive bilateral vertebral artery dissection. Neurosonologic tests were used for assessment and monitoring of the dissection. MRA confirmed the diagnosis. Brain MRI revealed multiple bilateral ischemic lesions in the posterior circulation. Careful history taking revealed transient ischemic symptoms 2 months before the patient's presentation to the NER, pointing to the long-lasting and oligosymptomatic course. The clinical picture was masked with the history of migraine with aura, depressive symptomatology, and stress. Risk factors were migraine, recent infection, and low $\mathrm{BMI}^{1,3}$.

Neurosonology was an excellent tool for screening of the dissection, and enabled daily bedside monitoring of the disease course, showing progression of the dissection despite ameliorated clinical course and regression of the symptoms. Previous neurosonologic studies showed high sensitivity of extracranial color Doppler for the assessment of CCAD ${ }^{13,16-20}$. Baracchini et al. ${ }^{16}$ demonstrated the value of neurosonology in daily monitoring of the dissection and thus revealed an even higher rate of recurrence of $27 \%$ in unaffected arteries.

Anticoagulation with heparin did not prevent progression of the extent of dissection but stopped embolization and the patient improved clinically. The choice between antithrombotic agents or anticoagulants is based on empirical arguments such as the presence, size and distribution of brain infarcts ${ }^{1}$. Although $\mathrm{Co}^{-}$ chrane systematic review, meta-analysis of observational studies and feasibility Cervical Artery Dissection and Ischemic Stroke Patients (CADISP) study have not suggested any significant difference between the impact of anticoagulants and antiplatelet agents on death and disability, or on the risk of cerebral infarction $^{21}$, anticoagulation in our patient was administered to prevent embolization. The introduction of anticoagulation had no impact on hematoma growth in either vertebral artery. Since the symptoms resolved, the explanation is that therapy suspended further embolization. The rate of recurrence of progressive cerebral ischemia after treatment initiation is low in patients 
with CCAD, less than 3\% in the largest observational studies, occurring mostly within the first weeks after the diagnosis ${ }^{21-24}$.

The risk factors in our patient were migraine, low $\mathrm{BMI}$, and probable infection, according to increased leukocyte count. Previous findings in patients with CCAD showed that patients with multiple and single artery dissection differed. In the largest prospective study of patients with CCAD, the CADISP study displaying characteristics and outcomes in multiple $\mathrm{CCAD}^{25}$, multiple artery dissections were associated with cervical pain at admission, remote history of head or neck surgery, a recent infection, and cervical manipulation. Our patient had cervical pain at admission, had undergone thyroidectomy, and had increased leukocyte count. However, neck trauma did not precede the dissection and no underlying vasculopathy was found.

Careful history taking revealed transient ischemic symptoms persisting for 2 months before presentation, and progression of the hematoma growth in both vertebral arteries suggested a progressive course. Some investigators consider multiple artery dissection as an early recurrent disease occurring sequentially within a short time frame ${ }^{3}$. Therefore, some investigators consider early CCAD recurrences and multiple CCAD as the same entity ${ }^{1}$. The presentation of our patient fitted this theory.

In conclusion, we presented a 40-year-old female patient with dissection of both vertebral arteries that progressed within the first two weeks despite amelioration of the patient's clinical status. Two months before presentation, she suffered transient ischemic symptoms, which could have been the first symptoms of the dissection. Risk factors were migraine, low BMI, thyroidectomy as a previous neck surgery, and probably a recent infection. The symptoms regressed with the introduction of anticoagulation therapy.

\section{References}

1. Debette S, Leys D. Cervical artery dissection: predisposing factors, diagnosis and outcome. Lancet Neurol. 2009;8:668-78, https://doi: 10.1016/S1474-4422(09)70084-5.

2. Lovrenčić-Huzjan A, Vuković V, Ažman D, Bene R, Demarin $\mathrm{V}$. Pain and ischemic symptoms in craniocervical artery dissection. Acta Med Croat. 2008;62:223-7.

3. Debette S. Pathophysiology and risk factors of cervical artery dissection: what have we learnt from large hospital-based cohorts? Curr Opin Neurol. 2014;27:20-8, https://doi: 10.1097/WCO.0000000000000056.
4. Engelter ST, Ground-Ginsbach C, Metso TM, Metso AJ, Kloss M, Debette S, et al.; for the Cervical Artery Dissection and Ischemic Stroke Patients (CADISP) Study Group. Cervical artery dissection. Trauma and other potential mechanical trigger events. Neurology. 2013;80:1950-7, https://doi: 10.1212/WNL.0b013e318293e2eb.

5. Čerimagić D, Glavić J, Lovrenčić-Huzjan A, Demarin V. Occlusion of vertebral artery, cerebellar infarction and obstructive hydrocephalus following cervical spine manipulation. Eur Neurol. 2007;58:248-50.

6. Rist PM, Diener H CH, Kurth T, Schurks M. Migraine, migraine aura, and cervical artery dissection: a systematic review and meta-analysis. Cephalalgia. 2011;31:886-96, https://doi: 10.1177/0333102411401634.

7. Metso TM, Tatlisumak T, Debette S, Dallongeville J, Engelter ST, Lyrer PA, et al. Migraine in cervical artery dissection and ischemic stroke patients. Neurology. 2012;78:1221-8.

8. Bejot Y, Aboa-Eboule C, Debette S, Pezzini A, Tatlisumak T, Engelter ST, et al.; on behalf of the CADISP Group. Characteristics and outcome of patients with multiple cervical artery dissection. Stroke. 2014;45:37-41, https://doi: 10.1161/STROKEAHA.113.001654.

9. Lee VH, Brown RD Jr, Mandrekar JN, Mokri B. Incidence and outcome of cervical artery dissection: a population-based study. Neurology. 2006;67:1809-12.

10. Arnold M, Kappeler L, Georgiadis D, Berthet K, Keserue B, Bousser MG, et al. Gender differences in spontaneous cervical artery dissection. Neurology. 2006;67:1050-2.

11. Schievink WI, Mokri B, O'Fallon WM. Recurrent spontaneous cervical artery dissection. N Engl J Med. 1994;330:393-7.

12. Lovrenčić-Huzjan A, Jurašić MJ, Lovrenčić-Prpić G, Vuković $\mathrm{V}$, Demarin V. Aortic arch dissection presenting with hemodynamic spectrum of aortic regurgitation on transcranial Doppler. Ultraschall Med. 2006;27:280-3.

13. Lovrenčić-Huzjan A, Bosnar-Puretić M, Vuković V, Demarin V. Sonographic features of craniocervical artery dissection. Acta Clin Croat. 2002;41:307-12.

14. Lovrenčić-Huzjan A, Klanfar Z, Bosnar-Puretić M, Demarin V. Embolic stroke due to internal carotid dissection: noninvasive monitoring of recanalization by color Doppler flow imaging and transcranial Doppler. Acta Clin Croat. 2002;42:201-5.

15. Lovrencic-Huzjan A. Diagnosis of non-atherosclerotic carotid disease. Perspect Med. 2012;1:244-9, https://doi: 10.1016/j.permed.2012.03.004

16. Baracchini C, Tonello S, Menaghetti G, Ballotta E. Neurosonographic monitoring of 105 spontaneous cervical artery dissections: a prospective study. Neurology. 2010;75:1864-70, https://doi: 10.1212/WNL.0b013e3181feae5e.

17. Nedbelsieck J, Sengelhoff C, Nassenstein I, Maintz D, Kuhlebaumer G, Nabavi DG, et al. Sensitivity of neurovascular ultrasound for the detection of spontaneous cervical artery dissection. J Clin Neurosci. 2009;16:79-82, https://doi: 10.1016/j.jocn.2008.04.005. 
18. Nedeltchev K, Bickel S, Arnold M, Sarikaya H, Sturzenegger M, Mattle HP, et al. Recanalization for spontaneous carotid artery dissection. Stroke. 2009;40:499-504, https://doi: 10.1161/STROKEAHA.108.519694.

19. Sturzenegger M, Mattle HP, Rivoir A, Rihs F, Schmid C. U1trasound findings in spontaneous extracranial vertebral artery dissection. Stroke. 1993;24:1910-21.

20. Sturzenegger M, Mattle HP, Rivoir A, Baumgartner RW. U1trasound findings in carotid artery dissection: analysis of 43 patients. Neurology. 1995;45:691-8.

21. Lyrer P, Englelter S. Antithrombotic drugs for carotid artery dissection. Cochrane Database Syst Rev. 2010; CD000255, https://doi: 10.1002/14651858.CD000255.pub2.

22. Kennedy F, Lanfranconi S, Hicks C, Reid J, Gomperts P, Price $\mathrm{C}$, et al. Antiplatelets vs anticoagulation for dissection:
CADISS nonrandomized arm and meta-analysis. Neurology. 2012;79:686-9, https://doi: 10.1212/WNL.0b013e318264e36b.

23. The CADISS Investigators. Antiplatelet treatment compared with anticoagulation treatment for cervical artery dissection (CADISS): a randomised trial. Lancet Neurol. 2015;14:361-7, https://doi: 10.1016/S1474-4422(15)70018-9.

24. Arauz A, Ruiz A, Pacheco G, Rojas P, Rodriguez-Armida M, Cantu $\mathrm{C}$, et al. Aspirin versus anticoagulation in intra- and extracranial vertebral artery dissection. Eur J Neurol. 2013;20: 167-72, https://doi: 10.1111/j.1468-1331.2012.03825.x.

25. Bejot Y, Aboa-Eboule C, Debette S, Pezzini A, Tatlisumak T, Engelter R, et al. Characteristics and outcomes of patients with multiple cervical artery dissection. Stroke. 2014;45:37-41, https://doi: 10.1161/STROKEAHA.113.001654.

Sažetak

\section{OBOSTRANA DISEKCIJA VERTEBRALNIH ARTERIJA - VIŠESTRUKO ZAHVAĆANJE ARTERIJA ILI RANA REKURENCIJA?}

\section{A. Lovrenčić-Huzjan, M. Bosnar-Puretic, V. Vuković-Cvetković i V. Bašić Kes}

U određenom postotku bolesnika s disekcijom kraniocervikalnih arterija disekcija zahvaća više arterija. Neki ispitivači smatraju da su disekcije koje su bile dijagnosticirane kao višestruke vjerojatno nastale jedna za drugom unutar kratkog razdoblja. Opisuje se oligosimptomatska bolesnica koja je imala obostranu disekciju vertebralnih arterija koja je progredirala. Pozorno uzimanje anamneze dodalo je podatke o prolaznoj slabosti lijeve ruke dva mjeseca prije hospitalizacije kao mogućnost ranijeg početka bolesti.

Ključne riječi: Disekcija vertebralne arterije, obostrana; Moždani udar; Neurosonologija; Praćenje 